\title{
KEBAHAGIAAN PADA REMAJA WANITA YANG BERULANG-ULANG PUTUS CINTA
}

\author{
Rebecca Pramudianti ${ }^{*}$ \\ ${ }^{1}$ Universitas Kristen Satya Wacana Salatiga, Indonesia \\ "e-mail: pramudiantirebecca97@gmail.com
}

\begin{abstract}
Abstrak
Tujuan dari penelitian ini adalah untuk mengkaji kebahagiaan yang dimiliki pada remaja wanita yang berulang kali mengalami putus cinta. Penelitian ini menggunakan pendekatan kualitatif dengan metode studi kasus. Subjek adalah dua orang remaja wanita berusia 20 tahun dan 19 tahun yang mengalami putus cinta lebih dari lima kali dan hal tersebut membuatnya mengalami sakit hati yang mendalam. Penggalian data pada penelitian ini menggunakan teknik wawancara dan menggunakan teknik analisis tematik theory driven. Hasil dari penelitian menunjukkan bahwa remaja wanita yang mengalami putus cinta berulang sempat mengalami sakit hati mendalam dan kecewa hingga ia mengambil keputusan untuk tidak ingin berpacaran lagi bahkan ingin menutup hatinya. Kebahagiaan yang dimiliki mulai nampak ketika seseorang dapat memiliki resiliensi dalam menghadapi permasalahan, memiliki temperance, serta sikap optimisme untuk kehidupan yang akan datang.
\end{abstract}

Kata kunci: Putus Cinta; Kebahagiaan; Resiliensi; Temperance; Optimisme

\begin{abstract}
The purpose of this study is to examined happiness in adolescent women who experienced a broke up. This research used a qualitative approach with a case study method. The subject was 20 years old and 19 years old adolescent women who experienced a break up more than five times. The experience of repeated broke up made her deep and prolonged heartaches. Data mining (collection) used in this study were interview techniques and theory-driven thematic analysis techniques. The study results show that adolescent women experiencing repeat breakups decide not to want date again or even they close their hearts. However, there is happiness found in the subject of repeat breakups. Happiness begins to appear when the subjects can have resilience in dealing with problems. He gives all to God to face a difficult time in his life. Another happiness seems when they have temperance, forgive, control emotions not to dissolve in disappointment and pain, and have an attitude of optimism for life to come.
\end{abstract}

Keywords: Breakups; Happiness; Resilience; Temperance; Optimism

\section{PENDAHULUAN}

Setiap tanggal 10 Oktober diperingati sebagai Hari Kesehatan Jiwa Sedunia. Hal tersebut merupakan sebuah permasalahan yang serius, kondisi-kondisi tersebut seperti depresi, kegelisahan, perubahan suasana hati hingga stres. Tujuan dari WHO memperingati Hari Kesehatan Jiwa Sedunia adalah untuk meningkatkan kesadaran masyarakat terkait kesehatan mental sehingga bisa mencegah terjadinya penyakit jiwa (Kementerian Kesehatan Direktorat Promosi Kesehatan dan Pemberdayaan Masyarakat., 2018). Sementara itu dalam Rencana Aksi Kegiatan 2015-2019 Direktorat Pencegahan dan Pengendalian
Masalah Kesehatan Jiwa Dan NAPZA mengemukakan bahwa faktor-faktor pemicu terjadinya gangguan jiwa tersebut antara lain faktor biologis (seperti faktor bawaan, penyakit infeksi virus, malaria cerebral, penyakit degeneratif, kecelakaan di kepala), faktor psikologis (kepribadian kurang matang, trauma psikologis masa lalu, konflik batin, dan keinginan yang tidak tercapai sehingga menimbulkan frustrasi), faktor sosial seperti masalah hubungan dalam keluarga, konflik dengan orang lain, masalah ekonomi, pekerjaan dan tekanan dari lingkungan sekitar, hingga keadaan bencana. Menurut Riset Kesehatan Dasar
(2018) terjadi peningkatan proporsi 
gangguan jiwa dari 1,7\% pada tahun 2013 naik menjadi $7 \%$ di tahun 2018 . Sedangkan menurut program kesehatan Jakarta, terdapat sekitar 4000 warga Jakarta yang terindikasi mengalami gangguan jiwa. Salah satu pemicu gangguan tersebut adalah putus cinta (Fajri, Kumparan News 2018). Selain itu, putus cinta juga menjadi faktor utama kasus bunuh diri di wilayah Semarang. Menurut Kasubag Humas, Polrestabes Semarang, penyebab aksi bunuh diri rata-rata diakibatkan stres atau depresi lantaran himpitan ekonomi dan persoalan asmara. Namun pada remaja dilatar belakangi adanya persoalan asmara (Nurchamim, Radar Semarang 2018).

Cinta dan manusia merupakan hal yang tidak bisa dipisahkan, tak terkecuali dalam kisah percintaan remaja. Sebelum merasakan adanya sebuah perpisahan dengan kekasihnya atau yang disebut dengan putus cinta, seseorang tentunya merasakan jatuh cinta terlebih dahulu dan menjalin relasi romantis. Pada fase ini remaja mengenal adanya relasi romantis yang diawali dengan kedekatan dengan teman sebaya. Pada saat itu remaja memiliki kebutuhan akan kelekatan dan kebutuhan seksual (Hurlock, 1980). Perilaku tersebut mengarahkan remaja pada perilaku berpacaran. Hal tersebut merupakan upaya untuk mecapai hubungan baru yang lebih matang dengan lawan jenis.

Menurut Papalia, et al (2008) masa remaja berada pada rentang usia 11-20 tahun. Pada masa ini remaja mengembangkan sebuah identitas seksual. Hal ini mencakup kemampuan belajar untuk mengelola perasaan seksual seperti ketergugahan dan ketertarikan seksual, mengembangkan bentuk intimasi yang baru, serta mempelajari keterampilan untuk mengelola tingkah laku seksual agar terhindar dari konsekuensi yang tidak diinginkan (Santrock, 2012). Masa tersebut merupakan masa pergolakan yang diisi dengan konflik dan mood yang mudah berganti-ganti serta banyak dipengaruhi oleh lingkungan dan teman-teman sebaya.

Berpacaran memang tak selamanya berjalan mulus, terdapat juga lika-liku yang harus dilalui. Terutama berpacaran yang dijalani oleh remaja, terkadang mereka akan merasa senang yang berlebihan ataupun sedih yang berlebihan pula. Hal ini dikarenakan pada masa tersebut emosi remaja masih labil. la akan mudah tersinggung, emosi yang meluap-luap dan sulit untuk mengendalikannya. Memang resiko dalam menjalin hubungan adalah putus cinta. Untuk itu putus cinta adalah hal yang tidak bisa dihindari dalam sebuah hubungan. Putus cinta adalah berakhirnya suatu hubungan yang dibina selama beberapa waktu tertentu yang dapat menimbulkan duka dan masa berkabung (Sonna, 2007). Menurut Yuwanto (2011) putus cinta merupakan kejadian berakhirnya suatu hubungan cinta yang telah dijalin dengan pasangan. Jadi, putus cinta adalah saat dua orang sepakat mengakhiri hubungan yang telah dijalin untuk beberapa waktu tertentu dan merasakan perasaan sedih dengan berakhirnya hubungan tersebut.

Ada beberapa faktor penyebab putusnya hubungan cinta yang muncul pada setiap pasangan, yaitu terlalu banyak menyimpan rahasia, cemburu atau hilangnya kepercayaan, ditentang keluarga, mencintai orang lain, cinta sesaat, dan hubungan jarak jauh (Lindenfield, 2005). Beberapa faktor tersebut mengarah pada hubungan yang berada di ujung tanduk. Apabila masing-masing individu mampu menyelesaikan masalah dengan cara yang baik, maka sebuah hubungan dapat terselamatkan. Tetapi bila hal tersebut tidak dapat terselesaikan, maka akan menyebabkan kehancuran hubungan.

Saat hubungan yang dijalin berakhir begitu saja, wajar bagi seseorang yang mengalaminya untuk merasakan sedih. Namun, sedih yang berlebihan juga akan membawa dampak yang tidak baik. Perlu adanya sebuah pengelolaan emosi yang tepat agar menimbulkan adanya kebahagiaan dan suasana hati yang positif. Menurut (Seligman, 2005) adanya kebahagiaan dapat membuat individu lebih objektif menyikapi sesuatu, kreatif, toleran, tidak defensif, murah hati dan lateral atau mampu memecahkan masalah secara kreatif. Kebahagiaan akan menekankan pada kesejahteraan subjektif dalam bentuk kepuasan penuh terhadap hidup atau pencapaian pada kenikmatan yang tinggi. Menurut (Seligman, 2005) terdapat beberapa aspek kebahagiaan yaitu bertahan dalam menghadapi tekanan dan dapat bangkit dari situasi tersebut yang disebut dengan resiliensi, dapat menjalin hubungan positif dengan orang lain sehingga dapat mengembangkan diri dan mampu untuk memecahkan masalah, memiliki keterlibatan penuh baik secara fisik, hati, pikiran dalam suatu aktivitas secara penuh, dapat menemukan makna dalam keseharian dari setiap apapun yang 
dilakukan, serta memiliki optimisme dalam menjalani kehidupan, memiliki impian dan harapan yang positif tentang masa depan.

$$
\text { Seligman (2005) memandang }
$$

bahwa setiap manusia memiliki potensi baik dan potensi buruk atau negatif. Dengan mengembangkan potensi positif yang dimiliki maka hal tersebut dapat membuat adanya rasa penderitaan dapat berkurang. Pada akhirnya hal tersebut akan membawa individu pada arah kebahagiaan. Sebuah kebahagiaan tidak hanya sekedar tertawa, tetapi dimaknai sebagai sesuatu kehidupan yang lebih bermakna, yang mana didalamnya terdapat nilai-nilai kebaikan. Nilai kebaikan tersebut antara lain adalah memaafkan sesuatu yang telah terjadi, menerima keadaan tersebut dengan lapang dada, mampu memberikan kasih sayang terhadap orang lain atau yang disebut dengan temperance.

Terdapat faktor-faktor yang memengaruhi kebahagiaan, menurut Seligman (2005) emosi masa lalu, masa sekarang, masa depan adalah faktor internal yang menentukan kebahagiaan seseorang. Serta lingkungan sebagai faktor eksternal yang memengaruhi kebahagiaan. Ketika seseorang mengalami kurangnya kebahagiaan ia akan nampak murung dan mengucilkan diri dari lingkungan sekitar. Dalam situasi tersebut individu menjadi gampang curiga, suka menyendiri, defensif berfokus pada kebutuhan sendiri (Seligman, 2005). Adanya ketidakbahagiaan dapat menimbulkan hancurnya penyesuaian diri baik secara sosial maupun pribadi (Hurlock, 1980). Oleh karena itu remaja perlu memiliki adanya emosi positif yaitu kebahagiaan agar ia dapat mengendalikan emosi negatif yang mungkin saja muncul saat mengalami putus cinta.

Hal tersebut didukung oleh penelitian milik Brenner dan Vogel (2015) yang dilakukan terhadap 475 mahasiswa Midwestern di Amerika, penelitian ini bertujuan untuk melihat adaptasi mahasiswa setelah putus cinta dengan mantan mereka. Hasilnya menunjukkan bahwa ketika seseorang semakin mengingat hal-hal yang baik dan menyenangkan mengenai mantannya maka hal tersebut berhubungan negatif dengan adaptasi yang dilakukan untuk bisa melupakan mantan. Demikian pula sebaliknya, ketika partisipan tidak mengingat hal-hal yang menyenangkan terkait mantan, hal tersebut berhubungan secara positif. Penelitian serupa juga dilakukan oleh Atrup dan Anisa, (2018) yang menyatakan bahwa remaja akan mengalami adanya rasa kekecewaan pasca putus cinta ketika ia susah melupakan orang yang dicintainya. Saat ia tidak bisa melupakannya maka dalam dirinya akan selalu timbul rasa kecewa sehinga akan membuat pikiran dan perilaku remaja tidak terkontrol, sehingga akan memperburuk keadaannya.

Penelitian lain milik Ulfah (2016) mengenai remaja yang mengalami putus cinta. Dalam penelitian didapatkan hasil yang menunjukkan bahwa semakin tinggi kematangan emosi seseorang maka semakin tinggi pula kebahagiaan yang dimiliki ketika menghadapi adanya perpisahan dalam suatu hubungan. Disebutkan pula bahwa seseorang yang mengalami putus cinta dapat menimbulkan dampak negatif pada dirinya seperti sedih berkelanjutan hingga depresi. Hal ini dikarenakan ia tidak memiliki kebahagiaan dan dijelaskan apabila kebahagiaan disebabkan oleh adanya kematangan emosi. Sementara hasil penelitian lain terhadap 81 remaja yang mengalami kegagalan cinta menyatakan bahwa semakin tinggi perasaan mengenai kegagalan cinta yang, maka semakin tinggi pula tingkat depresinya (Sri dan Agus, 2016). Remaja tersebut mengalami depresi ringan yang ditandai oleh kesedihan, harga diri rendah, rasa bersalah, putus asa, kemurungan, kelesuan, dan tidak memiliki gairah hidup. Hal ini disebabkan karena emosi yang labil, frustasi, dan kekecewaan yang mendalam.

Penelitian lain milik Dianovinina,
(2018) yang dilakukan pada 230 mahasiswa di Surabaya yang berpotensi mengalami depresi dan mahasiswa yang depresi. Remaja menghadapi banyak permasalahan dalam masa hidupnya. Adanya hal tersebut dapat menjadi salah satu faktor yang menyebabkan potensi risiko depresi pada remaja. Terlebih pada masa tersebut adalah usia rawan atau masa transisi seorang remaja. Dalam penelitian tersebut diidentifikasi gejala depresi di antaranya menganggap diri buruk, sulit berkonsentrasi, kehilangan minat untuk melakukan aktivitas, perubahan berat badan yang cukup drastis, dan sulit tidur sepanjang malam. Permasalahan remaja yang dapat menyebabkan terjadinya depresi ataupun remaja yang berpotensi mengalami depresi dapat disebabkan oleh permasalahan dari dalam diri dan dari luar diri (lingkungan). 
Salah satu faktor permasalahan dari luar diri adalah kehilangan seseorang yang disayangi. Adanya kehilangan ataupun kegagalan yang dirasakan remaja saat beranjak dewasa akan memicu terjadinya depresi (Santrock, 2003).

Oleh sebab itu, peneliti merasa bahwa adanya penelitian sebelumnya mendorong untuk menggali lebih dalam mengenai putus cinta yang dialami oleh remaja. Terlebih dari beberapa penelitian yang sudah dipaparkan di atas penelitian tersebut lebih mengarah pada penelitian kuantitatif, penelitian lebih berfokus untuk mengetahui terdapat hubungan atau tidak dan lebih berfokus pada dampak yang terjadi setelah berakhirnya suatu hubungan.

Pada penelitian ini, peneliti fokus untuk menggali kebahagiaan yang dimiliki partisipan setelah putus cinta sebagai salah satu cara untuk bertahan dari segala dampak negatif yang ditimbulkan akibat berpisah dengan kekasihnya. Lebih memfokuskan pada kompleksitas kebahagiaan wanita yang berulang mengalami putus cinta dalam perjalanan hidupnya. Terlebih pada masa remaja adalah masa yang disebut dengan storm and stress, yang artinya pada masa ini remaja mengalami banyak "badai dan tekanan jiwa", masa mengalami perubahan fisik, intelektual, emosional yang menyebabkan kesedihan dan kebimbangan (konflik) pada yang bersangkutan (Stanley Hall dalam Santrock, 2005). Sehingga pemilihan remaja sebagai partisipan dinilai menarik dalam penelitian ini untuk dapat diketahui lebih lanjut mengenai kebahagiaan yang dimilikinya setelah mengalami putus cinta.

\section{METODE}

Penelitian ini menggunakan pendekatan kualitatif dengan metode studi kasus. Pendekatan kualitatif digunakan untuk menjawab pertanyaan penelitian untuk mengkaji secara mendalam mengenai permasalahan. Kriteria subjek yang digunakan adalah remaja wanita, mengalami putus cinta lebih dari lima kali, dan mengalami sakit hati atas kejadian tersebut. Pemilihan subjek dilakukan dengan teknik bola salju yaitu mencari informasi dari orang lain secara berantai. Dengan kriteria tersebut, peneliti menemukan dua orang subjek yang berstatus mahasiswa di Salatiga. Subjek pertama adalah remaja wanita usia 20 tahun dan subjek kedua berusia 19 tahun.
Langkah pertama yang dilakukan oleh peneliti adalah menentukan karakteristik subjek yang digunakan untuk penelitian seperti yang telah disebutkan sebelumnya. Peneliti menggali informasi melalui wawancara terhadap subjek yang divalidasi dengan menggunakan triangulasi data pada teman sebaya, saudara, dan lingkungan sosial terkait subjek yang dibutuhkan. Sebelum mengambil data, peneliti terlebih dahulu mengumpulkan data melalui jurnal, artikel penelitian dan penelitian yang pernah dilakukan. Langkah selanjutnya peneliti mengumpulkan data melalui wawancara dan observasi yang dilakukan sebanyak lima kali termasuk kepada subjek dan kepada significant others.

\section{HASIL DAN PEMBAHASAN}

Dalam memaparkan hasil penelitian, peneliti menyajikan narasi kasus TP dan DN terlebih dahulu sebagai ilustrasi dan gambaran bagi pembaca. Selanjutnya peneliti menyajikan tema-tema yang muncul.

\section{Narasi Kasus TP}

TP merupakan seorang mahasiswi perantauan yang berumur 20 tahun. Aktivitas TP sehari-hari adalah berkuliah dan menyelesaikan tugas akhirnya yaitu skripsi. la menyebutkan bahwa banyak waktunya diisi dengan menghabiskan waktu bersama teman-teman dan digunakan untuk nongkrong. TP seorang yang ramah dan memiliki banyak relasi. Hal ini nampak tiap kali wawancara yang dilakukan di kos TP, saat melewati kamarkamar kos yang terbuka selalu saja ada yang memanggil nama TP dan ia berbalik menyapa dan sedikit bercanda dengan teman kosnya. Tak hanya itu, dari wawancara yang dilakukan pun menggambarkan bahwa TP sering menghabiskan banyak waktunya bersama teman-temannya yang mencerminkan bahwa ia seseorang yang memiliki banyak kawan.

Selama perjalanan hidupnya, TP mengalami jatuh bangun dalam membingkai kisah cintanya. TP mulai berpacaran sejak masih kelas 1 SMP, ia merasa saat itu ia mengalami cinta monyet. Baginya berpacaran saat itu adalah pacaran yang tidak serius, ia hanya sekedar berkirim pesan saja. Cinta monyet kala itu berlangsung selama 7 bulan, hingga akhirnya ia putus dengan pacar pertamanya dikarenakan ia diselingkuhi. 
Menurutnya walaupun ia merasa pacaran hanya bermain-main saja, tetapi ia mengaku sakit hati karena perbuatan pacarnya kala itu yang berselingkuh dengan kakak angkatan di depan matanya. Hingga akhirnya ia mengambil keputusan untuk putus. Setelah itu ia menjalin kisah asmara baru dengan pacar yang kedua. Sama seperti kisah cinta yang sebelumnya, TP mengatakan bahwa ia merasa pacar yang kedua ini adalah cinta monyet baginya. la menjalin hubungan selama 2 bulan dan penyebab putusnya hubungan tersebut dikarenakan pacar TP berselingkuh. Kembali lagi TP harus mengalami rasanya sakit hati karena diselingkuhi oleh pacarnya. Selang beberapa bulan kemudian, ia kembali memiliki pacar baru yaitu pacarnya yang ketiga. Bersama pacar yang ketiganya ini berlangsung selama 1 bulan. Berpacaran sebanyak tiga kali diakui TP sebagai pengalaman yang menyakitkan dan sempat membuatnya trauma dan hampir tidak ingin berpacaran.

TP sempat berada dalam masa ia benar-benar ingin sendiri dan ingin menemukan seseorang yang serius untuk menjalin hubungan dengannya. Hingga akhirnya ia bertemu dan menjalin cinta dengan pacar yang keempat. Sebelum memutuskan untuk kembali membuka hatinya, TP harus memastikan bahwa pria yang dikenalnya kali ini adalah benar-benar seseorang yang ia cari. la tidak ingin sakit hati lagi untuk kesekian kalinya. TP memiliki kesan tersendiri terhadap pacarnya yang keempat ini. Selain dikarenakan ia sungguh menyayangi pacarnya kali ini, pacar TP saat itu adalah satu-satunya pacar yang dikenalkan dengan orang tuanya.

Selama berpacaran dengan yang pertama hingga ketiga ia selalu backstreet dan keluarga tidak mengetahui hubungan tersebut. Begitu besar harapan yang dimiliki TP kepada pacarnya yang keempat. Menurutnya pacarnya yang keempat adalah satu-satunya yang dapat mengerti dirinya, menerima apa adanya, dan memiliki hati yang sabar. Bagi TP, pacar yang keempat ini adalah sosok yang ia dambakan. Meskipun TP mengetahui bahwa ia dengan pacar yang keempat berbeda keyakinan. Namun, hal tersebut tidak menyurutkan niat dan harapan TP untuk memiliki impian besar bersama dengan pacarnya tersebut.

$$
\text { Selama menjalani masa }
$$

berpacaran dengan pacar yang keempat selama hampir 2 tahun tersebut, TP merasa nyaman dan menjalaninya dengan bahagia. la menyebutkan bahwa tidak banyak konflik selama ia berpacaran. Satu keinginannya dengan pacarnya yang keempat adalah untuk menikah. Menurutnya, masalah yang menjadi konsentrasinya saat berpacaran kala itu adalah mengenai berbeda keyakinan. la menginginkan agar pacarnya mengalah dan berpindah keyakinan agar mereka dapat melangsungkan pernikahan. Namun, setiap TP menyampaikan keinginan tersebut, pacar TP selalu memberikan penghiburan kepadanya dan memintanya untuk bersabar. Hingga akhirnya mereka sama-sama mengambil keputusan untuk mengakhiri hubungan yang selama ini terjalin dan mengubur harapan untuk menuju pada arah yang lebih serius. Kejadian ini sangat membekas pada diri TP dan membuatnya butuh waktu lama untuk bisa pulih dari rasa sakitnya tersebut. TP merasa menjalin hari-hari tanpa pacar yang keempat adalah hal terberat bagi dirinya dan ia belum pernah merasakan putus cinta hingga seperti itu.

Membutuhkan waktu sekitar 2 tahun untuk TP benar-benar bisa melepaskan dan merelakan pacar yang keempatnya. la mengambil keputusan untuk merelakannya saat mantan yang keempatnya tersebut diduga telah dekat dengan wanita lain. Seketika TP merasa bahwa saat itu adalah waktu yang tepat baginya. Beberapa waktu setelah kejadian tersebut, TP mulai bisa membuka hatinya kembali untuk mengenal pria. Namun, kali ini ia begitu cepat mengenal dan dekat dengan seseorang pria dan dengan cepat pula ia memutuskan untuk berpacaran dengannya sebagai pacarnya yang kelima. Akan tetapi, hubungannya kali ini hanya bertahan selama 1 bulan.

\section{Narasi Kasus DN}

DN subjek kedua juga merupakan anak rantau di salah satu Universitas di Salatiga. Menurut penuturunannya, ia sudah mulai jatuh cinta sejak ia SD. Hal ini dikarenakan ia terlalu sering bermain dengan lawan jenis baik itu di sekolah dan di rumah. Sejak kecil DN terbiasa bermain dengan teman-temannya, dikarenakan orang tua yang sibuk bekerja. la menceritakan bahwa masa kecilnya diasuh oleh kakaknya. Sehingga ia merasa bahwa ia lebih dekat dengan saudara kandungnya dibandingkan dengan orang tuanya. Selain itu, DN merasa nyaman dengan selalu 
menjalin relasi dengan lawan jenis sejak $\mathrm{SD}$.

DN mengakui bahwa dirinya adalah seseorang yang selalu menuntut terhadap pasangannya, ia menginginkan pasangan yang sesuai kriterianya, seperti berwajah tampan, memiliki postur tubuh yang bagus, memiliki iman yang kuat, tidak pelit, open minded, dan karakteristik sifat yang bagus lainnya. Sehingga ia merasa bahwa ia memang seorang yang pemilih dalam hal pasangan. Hingga akhirnya saat ia berada di kelas tiga SMP, ia menemukan seseorang pria yang menurutnya susah untuk ditemukan. Pria yang sesuai dengan yang diharapkannya sejak ia mulai jatuh cinta. Pertemuan DN dengan pacar pertamanya ada di tempat ibadah. Hal ini dinilai DN bahwa tempat ia bertemu dan berkenalan dengan pria tersebut memberikan tanda positif bahwa pria ini memanglah dikirimkan untuknya. Selama berpacaran, DN menilai bahwa pacar pertamanya selalu ingin dipenuhi semua keinginannya. la pribadi yang keras kepala, tetapi hal itu bisa diterima olehnya. DN mengatakan bahwa ia yang memilih mengalah dan ikut memenuhi keinginan pacarnya.

Belum ada setahun berpacaran, pacar pertama DN harus pindah ke kota lain dikarenakan ia mengikuti kedua orang tuanya yang harus pindah. Hal itu menurut DN sulit untuk diterimanya, tetapi pacar DN meyakinkannya untuk tetap tenang dikarenakan pasti akan kembali untuk DN. Akan tetapi, begitu pacar DN pergi, ia tidak memberikan kabar sedikitpun padanya. DN mengatakan bahwa ia tidak mengetahui keberadaan pacarnya saat itu ataupun bagaimana kondisinya. Karena setelah pergi, pacar DN sama sekali tidak berkomunikasi dengannya. DN merasa pacarnya hanya memberikan harapan padanya yang kemudian meninggalkannya. DN kemudian menilai bahwa semua pria sama saja yang hanya memberikannya harapan lalu pergi. DN merasa sakit hati dengan perlakuan yang ditinggalkan begitu saja. Semenjak kejadian itu ia tidak ingin untuk jatuh cinta kembali, ada ketakutan dalam dirinya apabila ia membuka hati dan disakiti kembali. Kejadian itu membuatnya menjadi semakin sering main keluar daripada di rumah, ia menjadi mencobacoba merokok, melakukan hal apapun untuk melupakan pacar pertamanya. DN juga menyebutkan bahwa ia sengaja melakukan hal-hal tersebut sebagai pelarian dari sakit yang ditinggalkan pacarnya.

Beberapa bulan kemudian DN mulai berpacaran kembali dan ia berpacaran untuk kedua kalinya. DN mengatakan bahwa ia melakukan hal ini dikarenakan ia ingin membalaskan rasa sakit dari yang dia rasakan karena ditinggalkan oleh pacar pertamanya. DN merasa bahwa pria harus merasakan rasa sakit yang dirasakannya. Hal yang mendorong DN untuk mengambil keputusan tersebut ketika ia menceritakan kesedihannya kepada sahabatnya. Kemudian sahabatnya memberikan masukan bahwa ia akan rugi apabila menyia-nyiakan hidupnya. Sehingga DN merasa bahwa ia harus bertindak melakukan sesuatu, tidak boleh diam saja hanya merasakan sakit dan melakukan aktivitas yang hanya membuang waktu. DN bertekad bulat untuk berpacaran kembali dan berharap tujuannya tercapai. Belum ada satu bulan ia memutuskan pacar keduanya dengan alasan bahwa ia tidak cocok. DN merasa senang dengan tindakannya waktu itu. DN menuturkan bahwa ia akan berkomitmen untuk membangun relasi yang baik untuk menarik perhatian pria hingga siapapun yang menyatakan cinta padanya akan ia terima.

Setelah putus dengan pacar yang keduanya, DN kembali mencari pacar lagi. DN mengakui bahwa ia harus menjadi pihak yang memutuskan pacar. Bahkan saat DN merasa bahwa hubungannya seperti tidak baik ia harus segera memutuskan pacarnya sebelum ia yang diputuskan. DN kembali lagi untuk mencari pacar yang ketiga, hal ini dilakukannya hingga ia SMA. DN menyebutkan bahwa ia sempat memutuskan pria yang sempat menjadi pacarnya sebanyak 6 kali. DN menggunakan berbagai macam alasan untuk dapat putus. Selama beberapa kali putus dan kembali lagi berpacaran, DN sempat menyebutkan bila ia pernah diselingkuhi. la merasakan sakit karena beranggapan bahwa ada seseorang yang berani menyakitinya lagi. Walaupun DN sudah berkomitmen di awal, tapi tetap saja ada rasa sakit yang dirasakan DN ketika pasangannya menyelingkuhinya, tidak berkabar padanya, dan melakukan hal lain yang membuatnya sakit. Setelah beberapa kali selalu mencari kesalahan dari pacarpacarnya. DN merasa bahwa ada hal yang hilang dari hidupnya, ia tidak menemukan kenyamanan dalam hari-harinya. 


\section{Resiliensi}

Apabila dilihat dari kasus di atas, pengalaman sakit hati dirasakan oleh kedua subjek. Perasaan yang dirasakan TP merupakan hal yang menyakitkan dan tidak mudah diterima olehnya. TP mengakui untuk bangkit dan merelakan atas semua yang telah terjadi membutuhkan sebuah perjuangan. TP sempat mengalami sakit hati mendalam bahkan ia sempat mengambil keputusan untuk tidak ingin lagi membuka hatinya dan merasa bahwa ia trauma untuk berpacaran. $\mathrm{Hal}$ ini dikarenakan berulang kali ia disakiti oleh mantan, diselingkuhi, dan terdapat mantan TP yang memupuskan harapan yang dimiliki TP untuk menjalin hubungan ke arah yang serius. Pengalaman berpacaran berulang kali membuatnya mulai merasa lelah dengan hubungan yang selalu berakhir dengan kata putus tersebut.

Dalam melewati masa tersebut TP membutuhkan waktu untuk move on, dalam hal ini TP mendapat dukungan dari sahabat sebagai tempat ia curhat, mengajaknya nongkrong dan travelling bersama. TP merasa dengan mendapatkan support, motivasi dari sahabat, melakukan aktivitas lain dapat menjadi pelipur lara bagi dirinya dan menerima keadaan dapat membuatnya merasa lebih baik. Saat TP dapat kuat menjalani keadaan yang paling menyakitkan bagi dirinya dan bertahan agar bisa bangkit dari segala hal yang membuatnya terluka, ia merasa menjadi pribadi yang lebih baik. Hal tersebut membuatnya dapat membuka hati untuk menjalin relasi dengan lawan jenis dan memulai untuk berpacaran kembali.

Melewati pasang surut dalam kisah percintaanya, TP akhirnya mengambil sebuah komitmen. la memiliki prinsip bahwa ia akan mengutamakan hal mengenai seiman untuk memilih pasangan hidup ke depannya. TP tidak ingin jatuh lagi pada kesalahan yang dibuatnya secara berulang. la meyakini hal ini dikarenakan empat dari lima pria yang pernah menjadi pacarnya adalah mereka yang berbeda keyakinan dengannya. Terlebih dengan mantan keempat, TP merasa putus cinta yang terdalam dibandingkan pengalaman dengan mantan-mantan yang sebelumnya. Sehingga langkah TP untuk memiliki prinsip dengan meletakkan pria yang seiman dalam pilihan mengenai pasangan hidupnya adalah langkah yang dipilih untuk bisa bangkit dari rasa sakit hati. Dengan memiliki prinsip tersebut, TP akan lebih siap dalam bertahan sekalipun pada situasi yang menyakitkan.

Selain itu, TP merasa bahwa semua yang terjadi dalam kehidupannya adalah seijin Tuhan. la memiliki mindset bahwa semuanya sudah diatur Tuhan dan ia akan menyerahkan semua berdasarkan kehendak-Nya. TP mengungkapkan " $Y a$ ini jawaban yang dikasi dari Tuhaaaaannnn". Sehingga ketika ia memiliki pemikiran semacam itu hal tersebut akan membuatnya untuk tidak merasa terpuruk ataupun menyesali keadaan. Meskipun pada awalnya ia sempat menyalahkan keadaan, tidak menerima kenyataan, bahkan TP sempat menyalahkan Tuhan atas sakit hati dan perlakuan mantan kepadanya. Namun, ketika ia memiliki pemikiran seperti itu, dapat bertahan dan tetap mengusahakan yang terbaik untuk kembali membuka hatinya ia dapat membebaskan rasa sakit hatinya.

Sedangkan kasus yang dialami oleh DN, ia langsung merasakan sakit hati yang mendalam ketika pertama kali berpacaran. Salah satu hal yang membuatnya menjadi sangat sakit karena sejak SD ia telah memiliki impian berlebih mengenai sosok pria yang diinginkannya. DN mengatakan:

"Memang sih, aku tu gimana ya tipe cewek yang pemilih banget sebenernya apalagi ya soal pasangan. Yaaa idealis menurutku si aku tu idealin. Aku tu pengen cowok yang yaa perfeksionis, yaa ganteng, punya iman kuat, open minded, royal gitu nggak pelit".

Sehingga dengan harapan yang sudah dibangunnya sejak kecil, ia merasa akan menjadi seseorang yang diperhatikan, disayang dengan mendapatkan pria dengan kriteria tersebut. Namun, saat ia mulai menjalani relasi tersebut, pacar pertama DN pergi meninggalkannya hingga tidak memberikan kabar sedikitpun. Rasa nyaman yang dirasakan DN hanya sebentar dan berubah menjadi rasa sakit yang berkepanjangan. Sempat mengambil keputusan untuk tidak membuka hati kembali karena pengalaman menyakitkan tersebut hingga akhirnya ia memberanikan diri membuka hati kembali dengan suatu tujuan tertentu. DN yang ingin pria merasakan bagaimana rasa sakit yang dirasakan ketika ditinggalkan begitu saja. Tetapi hal tersebut nampaknya juga membuat DN tetap merasakan sakit hati dikarenakan ada pacar DN yang 
berselingkuh, tega memperlakukan DN demikian.

Rasa sakit hati DN berkepanjangan dan tidak membuatnya merasakan ada kenyamanan dengan terus melakukan tindakan demikian. DN merasa kehidupannya akan terus berada dalam sakit hati apabila ia tidak segera bangkit dan menerima adanya perubahan dalam kehidupannya. DN merasa yang dapat bertahan hidup di dunia dan yang bisa menikmatinya adalah mereka yang dapat bertahan dan melawan rasa sakit. DN mengatakan:

"Kalo aku terus-terusan gini ya gimana, harusnya kan aku yang menang dari rasa sakit. Bukan rasa sakit yang menang dari $a k u "$.

Terdapat proses dalam kehidupan DN hingga akhirnya ia memiliki kepercayaan diri untuk lepas dari rasa sakit efek pengalaman menyakitkannya di masa lalu. la memiliki keyakinan untuk melawan rasa sakit dengan memiliki pemikiran positif untuk tidak terjerat dalam rasa sakit hati dan kecewa dengan semua pria. Selain itu dukungan dari sahabatnya ikut memberikan sesuatu hal positif dalam diri DN. Walau pada awalnya masukan dari sahabatnya dimaknai dengan persepsi yang berbeda olehnya. Tetapi, akhirnya ia dapat memandang positif masukan dan saran yang diberikan sahabatnya kepada dirinya. Penuturan DN mengenai sahabatnya yang memberikannya nasehat:

"Aku cuma berani ceritain masalahku ini yaa ada sih sahabatku. Aku ceritain dia kalo si itu pergi gitu aja tanpa kabar, yang katanya mau pulang lagi demi aku. Terus ya dia kasi tau aku tuh panjang lebar, kalo gimanapun juga hidup harus tetep jalan, tanpa dia tu nggak bikin aku mati, masih banyak kok cowok lain nggak cuma dia aja".

Saat DN mulai belajar menerima masalah yang dihadapinya, menyadari kenyataan yang ada membuat DN untuk mulai mengikhlaskan kepergian mantan pacarnya serta memiliki pemikiran yang positif, serta mengambil sikap yang semestinya dilakukan dalam hidupnya.

\section{Temperance}

Selain adanya proses resiliensi pada diri TP dan DN untuk dapat bertahan dalam situasi menyakitkan bagi mereka, terdapat informasi yang menggambarkan kedua subjek sebagai individu yang dapat memaafkan, mengontrol keinginan dan emosinya dengan bijaksana. Hal ini nampak pada saat TP dapat menerima perbuatan dari tiap mantannya. la dapat dengan berlapang dada menerima setiap tindakan yang menyakiti hatinya bahkan sempat membuatnya tidak ingin berpacaran lagi karena merasa trauma apabila selalu terulang kisah cinta yang membuatnya sakit hati. TP dapat memaafkan perbuatan dari mantannya dan ia ikhlas apabila mantannya memiliki pacar baru. Dapat terlihat dari sikap TP terhadap mantannya yang keempat, ia bisa menerima pacar baru dari mantannya tersebut.

Tidak hanya menerima, bahkan ia bisa mendukung hubungan tersebut dengan lapang dada dan akan marah apabila mantan yang keempat putus dengan pacarnya. la berharap bahwa mantan yang keempat bisa menjalin hubungan dengan lebih baik, terlebih mantan yang keempat telah mendapatkan pacar yang seiman. Tentang hal ini TP mengatakan:

"Kan kenapa sih putus, kan bisa dibicarain baik-baik. Kan maksut e permasalahan kan bisa diomongin baik-baik. Maksute jangan gitu, kan ya udah dapet yang seiman kenapa gitu putus. Yaaa aku bilang diselesaiin, gini-gini gitu mbak".

Sikap memaafkan mantan juga dimiliki oleh DN yang mengatakan:

"Dia tau-tau pergi tanpa apa yaaaa, $\mathrm{hmm}$ ya orang kita bilang pamitan, ini nggak. Ya aku mulai merasa cinta ya disitu, bisa pakai pikiran, bisa ngalah, dia kurang aku tu ngisi. Yaa kloplah, buat bertengkar ya aku bisa meredam gitulah. Tapi, kalo emang itu pilihan dia buat ngilang ya gimana. Mungkin ada hal lain yang bikin dia ngelakuin ini semua. Mungkin akan ada waktunya buat aku tau, tapi kalo bukan sekarang ya nggak papa".

Ketika DN mau untuk mencoba memahami alasan seseorang pergi meninggalkannya dan memaafkan perbuatannya ia mendapatkan suatu rasa lega dalam hidupnya. Tanpa dia selalu mempertanyakan alasan dibalik rasa sakit yang diterimanya selama ini. Tindakan memaafkan dan mengikhlaskan perbuatan orang lain yang menyakitkan akan 
berdampak terhadap kehidupan seseorang. Dengan demikian maka tidak menimbulkan perasaan ingin balas dendam atau emosi negatif lainnya. Pencapaian DN dalam menghadapi permasalahan sakit hatinya ketika ia mampu untuk menghentikan rasa dendam pada setiap pria. Sehingga ia tidak hanya terfokus pada pemikiran untuk selalu menyakiti saja.

Sedangkan pada TP ia bersyukur bisa melewati tiap tahapan hingga saat ini. Sebesar dan seindah apapun harapan TP saat memiliki pacar dan memiliki keinginan untuk melangkah ke hubungan yang lebih serius dapat ia relakan. Awal setelah ia putus dengan pacarnya, ia merasa suntuk, sering menangis, mengalami hambatan dalam beraktivitas, gangguan makan, gangguan belajar, serta tidak semangat dalam menjalani aktivitas sehari-hari secara berlebihan. Sebenarnya, hal tersebut merupakan reaksi wajar dari seseorang yang mengalami putus cinta. Akan tetapi, menjadi sesuatu yang perlu mendapat perhatian apabila reaksi tersebut menganggu kehidupan individu yang putus cinta. Namun, TP tak tinggal diam menghadapi hal tersebut. la dapat menanggapi setiap kenyataan dengan pikiran terbuka, rileks, bisa mengontrol emosi untuk tidak larut dalam kesedihan, kekecewaan dan rasa marah yang mendalam. Dengan demikian ia dapat terlepas dari pikiran dan perasaan yang membuatnya terpuruk.

\section{Optimisme}

Sikap optimis dari TP terlihat dari kasus-kasus dalam penelitian yang sudah dilakukan. Dalam menghadapi putus cinta yang berulang kali, TP dapat mengambil sebuah hikmah dari kejadian yang telah terjadi tersebut. Menurutnya adanya hal tersebut membuatnya untuk bisa memperbaiki diri, mengambil pelajaran positif dan sebagai introspeksi diri baginya. TP mengatakan:

"Kalo aku sih setelah putus itu aku yaa belajar lagi, memperbaiki kesalahan. Yang lalu biarlah berlalu, buat pelajaran. Kalo seumpama Tuhan udah menentukan yaa aku belajar yang kemaren itu nggak keulang lagi. Maksute sifatku yang nggak baik itu, istilahe itu yang nggak aku tonjolkan".

Ketika TP dapat memaknai kejadian putus cinta sebagai sesuatu yang positif dan dapat melakukan pengelolaan emosi, maka ia dapat memiliki pengharapan mengenai masa depan yang lebih baik. Hal tersebut memberikannya semangat untuk hari depan yang lebih baik dibandingkan pengalaman di masa lalunya. Selain itu sebuah keinginan dalam diri TP yaitu menginginkan pasangan yang serius unntuk masa depannya. la mengatakan:

\begin{abstract}
"Yaa aku pengennya yaa kalo dapet sekarang yang tadi tujuannya buat yang serius nggak mau maen-maen. Lihat dari usia juga kan udah dewasa, cari yang bener-bener serius. Aku tu pengen serius satuuu, yang memuliakan Tuhan gitu, setia sama Tuhan, setia sama orang tuanyaaa, yaa sama saya, setia sama keluarga saya. Yaa kayak gitu sihh".
\end{abstract}

Dengan demikian ia dapat menjalani kehidupan yang lebih baik dengan sebuah harapan yang niscaya akan terwujud.

Sikap optimis juga ditunjukkan DN melalui penuturannya yang mengatakan bahwa ia memiliki mimpi yang lebih besar dari sekedar hanya mendapatkan pria yang sesuai dengan kriterianya. Berangkat dari latar belakang $\mathrm{DN}$ sendiri bahwa keluarganya merupakan pendidik rohani mulai dari kedua orang tuanya dan saudara tertuanya. Sehingga hal tersebut sedikit banyak memberikan pengaruh dalam diri DN untuk memiliki keinginan kedepannya bergerak dalam bidang yang sama. DN mengatakan:

"Aku tu korban, tapi aku tanamin mind set kalo ayolah ada masanya, ada waktunya. Aku nggak mau seumur hidupku kayak gini, aku punya cita-cita kok. Kalo masalah pasangan hidup, aku yakin aku akan dapat gantinya, aku yakin kalo aku nggak akan dapet yang lebih buruk".

Dengan memiliki keyakinan tinggi membantu DN untuk melalui hari-harinya tanpa rasa kecewa lagi. la meyakini bahwa mengenai pasangan hidup pasti akan ia dapatkan, tanpa dia harus mengkhawatirkan tidak mendapatkan yang sesuai kriterianya. Sebab dengan keyakinan hatinya ia tahu bahwa pasangan kedepannya tidak akan mendapat yang lebih buruk. Hal ini berarti ia yakin akan mendapatkan pasangan yang lebih baik dari sekedar apa yang dia inginkan. Di samping itu ia juga memiliki mimpi untuk memperjuangkan mimpinya. la menyadari bahwa ia tetap tinggal dalam situasi tersebut, tidak akan membawanya pada 
perubahan. Namun, akan membuatnya semakin terpuruk, sehinggal hal tersebut yang membantu DN untuk bergerak dan mengambil sikap demikian.

\section{SIMPULAN DAN SARAN}

Penelitian ini menunjukkan bahwa kebahagiaan pada remaja wanita yang mengalami putus cinta berulang kali dapat tercerminkan melalui sikap resiliensi dalam hidupnya. Ketika seseorang mampu bertahan dalam masalah, kuat menghadapinya, ia akan mampu untuk berpikir dan berperilaku dalam menghadapi masalahnya. Perilaku selanjutnya yang ia tunjukkan adalah suatu sikap temperance dengan memaafkan dan mengikhlaskan orang yang menyakiti hatinya. Setelah ia dapat melakukan hal tersebut, ia akan dapat menanamkan sikap optimis dan hal positif untuk kehidupannya yang lebih baik di masa mendatang. Meskipun sempat mengalami sakit hati yang terlalu dalam hingga memunculkan respon tertentu yang mengganggu aktivitas sehari-hari, hal ini dapat teratasi dengan adanya kebahagiaan. Sebuah kebahagiaan mampu untuk meminimalisir sakit hati seseorang yang disebabkan karena putus cinta dan membawa perubahan menuju yang lebih baik.

\section{DAFTAR PUSTAKA}

Atrup dan Anisa, Y. (2018). Hipnoterapi teknik part therapy untuk menangani siswa kecewa akibat putus hubungan cinta pada siswa sekolah menengah kejuruan. Jurnal Pinus, 4(1), 21-29.

Brenner, R. and Vogel D. (2015). Measuring thought content valence after a breakup: development of the positive and negative ex-relationship thoughts (panert) scale. Journal of Counseling Psychology, 62(3), 476487.

Dianovinina, K. (2018). Depresi pada remaja: gejala dan permasalahannya. Jurnal Psikogenesis, 6(1), 69-78.

Fajri. (2018). Sandi sebut putus cinta jadi salah satu penyebab gangguan jiwa. Kumparan. Retrieved from https://kumparan.com/@kumparanne ws/sandi-sebut-putus-cinta-jadisalah-satu-penyebab-gangguan-jiwa

Hurlock. (1980). Psikologi perkembangan suatu pendekatan sepanjang rentang kehidupan. Jakarta: Erlangga.

Kementerian Kesehatan Direktorat Promosi Kesehatan dan Pemberdayaan
Masyarakat. (2018). Hari kesehatan jiwa sedunia. Retrieved from http://promkes.kemkes.go.id/agenda/ hari-kesehatan-jiwa-sedunia

Lindenfield, G. (2005). Putus cinta bukan akhir segalanya. Jakarta: PT. Gramedia Pustaka Utama.

Nurchamim. (2018). Penyebab remaja depresi didominasi masalah asmara. Radar Semarang. Retrieved from http://radarsemarang.com/2018/01/1 5/penyebab-remaja-depresididominasi-masalah-asmara/

Papalia, D., Olds, S. W., \& Feldman, R. D. (2008). Human development: psikologi perkembangan. Jakarta: Kencana.

Riset Kesehatan Dasar. (2018). Potret sehat Indonesia dari riskesdas 2018. Retrieved from http://www.depkes.go.id/

Santrock, J. W. (2003). Adolescence. Eleventh edition. Boston: McGraw Hill International Edition.

Santrock, J. W. (2005). Adolescence: perkembangan remaja. Jakarta: Erlangga.

Santrock, J. W. (2012). Life-span development: perkembangan masa hidup edisi 13 jilid 1. (Widyasinta, Terjemahan). Jakarta: Erlangga.

Seligman. (2005). Authentic happiness: menciptakan kebahagiaan dengan psikologi positif. Bandung: PT. Mizan Pustaka.

Sonna, L. (2007). Memahami tentang membimbing anak remaja: sebuah panduan bagi orangtua dalam menghadapi berbagai masalah. Batam: Karisma Publishing Group.

Sri, M., \& Agus, A. (2016). Hubungan kegagalan cinta dengan terjadinya kejadian depresi pada remaja. LPPM Akes Rajekwesi Bojonegoro, 7(2), 23-26.

Ulfah, D. (2016). Kematangan emosi dan kebahagiaan remaja putus cinta. Jurnal IImiah Psikologi. Jurnal IImiah Psikologi, 9(1), 92-99.

Yuwanto, L. (2011). Reaksi umum putus cinta. Jurnal Ubaya. 